\title{
MANOVA Statistical Analysis of Inorganic Compounds in Groundwater Indonesia
}

\author{
Heruna Tanty ${ }^{1}$, Rokhana Dwi Bekti ${ }^{2}$, Tati Herlina ${ }^{3}$, Nurlelasari ${ }^{4}$ \\ ${ }^{1,2}$ Department of Mathematics and Statistic, ${ }^{3,4}$ Department of Chemistry \\ ${ }^{1,2}$ School of Computer Science, Bina Nusantara University \\ ${ }^{3,4}$ University of Padjadjaran
}

\begin{abstract}
The present study was carried out to determination a levels of inorganic compounds contained in the ground water and Reverse Osmosis (RO) water filtration result. The data in groundwater samples was collected from Bekasi, Tangerang and Jakarta in Indonesia. A total of 30 samples were collected and analyzed for the determination of Cadmium (Cd), Chromium (Cr), Manganese (Mn), Cyanide $(\mathrm{CN})$ and Lead $(\mathrm{Pb})$. The results of the study revealed that in groundwater, the average of Cd $0.0058 \mathrm{mg} / \mathrm{l}, \mathrm{Mn} 1.5233 \mathrm{mg} / \mathrm{l}, \mathrm{Cr} 0.0127 \mathrm{mg} /$, $\mathrm{Pb} 0.0060 \mathrm{mg} / \mathrm{l}$, and CN $0.0040 \mathrm{mg} / \mathrm{l}$. The level of RO result were: $C d 0.0027 \mathrm{mg} / \mathrm{l}, \mathrm{Mn} 0.1767 \mathrm{mg} / \mathrm{l}, \mathrm{Cr}$ $0.0024 \mathrm{mg} / \mathrm{l}, \mathrm{Pb} 0.0021 \mathrm{mg} / \mathrm{l}$, and CN $0.0023 \mathrm{mg} / \mathrm{l}$. It's mean that Cd and Mn in ground water were higher than the values recommended by PAK-EPA and WHO or the standard of Indonesian Ministry of Health. But after filtration Reverse Osmosis (RO) Mn and Cd levels decreased to levels below the standardized value. By comparing of mean in MANOVA and nonparametric MANOVA in $\alpha=5 \%$, there are differences in average levels of inorganic substances $\mathrm{Mn}, \mathrm{Cr}, \mathrm{Cd}, \mathrm{Pb}$, and $\mathrm{CN}$ between before and after RO filtration.
\end{abstract}

Keywords: Inorganic Compounds, Ground Water, Reserve Osmosis, MANOVA

PACS: 07.89. $+b, 02.50 . S k$

\section{Introduction}

Water is essential for human life. Functions of water in the body are cell life, chemical and metabolic reaction, transform of nutrients, body temperature regulation and elimination of waste [1]. Jakarta, Bekasi and Tangerang are a large region population in Indonesia. Water needs in these three areas is very high, but the local water company (PDAM) in Jakarta can only supply 39\% of the population water needs. Most people use water refills. Some of them consume Reverse Osmosis (RO) water filtration result, but many low-income peoples directly consume groundwater for drinking.

Jakarta, Bekasi and Tangerang have many industries and densely populated residential. Increase in the number of septic tanks polluting the groundwater and can have serious health effects diseases such as hepatitis and dysentery. Inorganic compounds such as Chrome $(\mathrm{Cr})$ reduces fatty acids and cholesterol and regulates sugar and insulin rates in the blood, but chronic exposure to high chromium levels causes lung cancer in human [2].

Groundwater for drinking has the potential to cause damage to liver, kidney, circulatory and nerve tissues and skin irritation from long-term exposures at levels above the Maximum Contaminant Level (MCL) [3]. Heavy metal toxicity like Lead $(\mathrm{Pb})$, Cadmium $(\mathrm{Cd})$, Manganese $(\mathrm{Mn})$ are can result in damaged or reduced mental and central nervous function, cancer, lower energy levels, and damage to blood composition, lungs, kidneys, liver, and other vital organs [4]. Therefore, the study of inorganic compounds in the groundwater and water filtration Reverse Osmosis (RO) result was done.

There are some statistical methods for analysis the water quality, such as Multivariate Analysis of Variance (MANOVA) [5], [6]. Function of MANOVA is comparison of dependent variable means across multiple groups. It requires that the observations are independent, the response variables are multivariate normally distributed, and the covariance matrix of the dependent variables is homogeneous across groups. This research use MANOVA to compare inorganic compounds in the ground water and RO. The results of MANOVA can determine the effect of RO filtration in water quality, and the differentiation of quality water in groundwater and RO. When assumption of MANOVA, homogeneity variance or normal distribution, was violated, then it can use nonparametric MANOVA [7], [8].

\section{Sampling}

\section{Methodology}

For the present investigation, there were 30 groundwater samples collected from different localities of Bekasi, Tangerang and Jakarta in Indonesia. The time of data collecting was during the months of May to August 2013. The samples were in screw high density polyethylene bottles. The sample bottles were rinsed 
twice with the sample water to avoid any impurity. It also labeled properly and immediately transferred to laboratory in Padjadjaran University in Bandung-Indonesia.

\section{Determination Of Lead (Pb) And Cadmium (Cd)}

Fifty $\mathrm{ml}$ of the test sample was inserted into beaker of $100 \mathrm{ml}$ or $100 \mathrm{ml}$ Erlenmeyer and add $5 \mathrm{ml}$ of $\mathrm{HNO}_{3}$ concentrated. It closed with watch glass then heated slowly until the residual volume of $15 \mathrm{ml}-20 \mathrm{ml}$. If destruction is not perfect (not clear), then added $5 \mathrm{ml}$ of $\mathrm{HNO}_{3}$ dense and closed with a watch glass and then heated again (do not boil). This process was done repeated until all dissolved metals, which looks sample of sediment color became somewhat white or test sample becomes clear. After the glass watch water was rinsed, put solute in the beaker. Then the test sample transferred into a $50 \mathrm{~mL}$ volumetric flask (filtered if necessary) and added demineralized water tera sign up right then homogenized. After the absorbance read at using AAS instrument [9], [10].

\section{Determination Of Chrome (Cr)}

Pipette a volume (V) of test sample and place in a $100 \mathrm{~mL}$ beaker, add $0.25 \mathrm{~mL}$ ( 5 drops) $\mathrm{H}_{3} \mathrm{PO}_{4}$, adjust to $\mathrm{pH} 2.0 \pm 0.5$ by addition $0.2 \mathrm{~N}$ sulfuric acid. Move the sample solution into $100.0 \mathrm{~mL}$ volumetric flask. For specify the calibration mark with demineralized water, add $2.0 \mathrm{~mL}$ of solution difenilkarbazida, shake and let stand 5 to 10 minutes; measuring absorbance at a wavelength of $530 \mathrm{~nm}$ or $540 \mathrm{~nm}$; record the measurement results [11].

\section{Determination Of Manganese (Mn)}

Include $100 \mathrm{~mL}$ sample that has been whipped up into a homogeneous beaker, add $5 \mathrm{~mL} \mathrm{HNMO}_{3}$, and heat in an electric heater until the solution sample dry. Then added $50 \mathrm{~mL}$ of distilled water, put into a flask of 100 filter paper and matched $\mathrm{mL}$ through $100 \mathrm{~mL}$ with distilled water [12].

\section{Determination Of Cyanide (CN)}

Pipette $10 \mathrm{ml}$ of standard solution of cyanide $( \pm 1000 \mathrm{mg} / \mathrm{l})$ to the Erlenmeyer (Duplo) and dilute with a solution of $0.04 \mathrm{M} \mathrm{NaOH}$ diluents by the volume of $\pm 100 \mathrm{ml}$ which use a blank $0.04 \mathrm{M} \mathrm{NaOH}$ solution. After that, add $1 \mathrm{ml}$ of indicator solution rodamina and do homogeneous process. Titar with standard- $\mathrm{AgNO}_{3}$ solution until the color changes from clear yellow first red-brown, and chartreuse. Note that the volume of $\mathrm{AgNO}_{3}$ standard solution worn on of Cianide $(\mathrm{CN})[13]$.

For analyze the research data, do the following steps:

\section{Data Analysis}

1. Conduct descriptive analysis covers the average, standard deviation, minimum value and maximum value for $\mathrm{Pb}, \mathrm{Cd}, \mathrm{Cr}, \mathrm{Mn}$, and $\mathrm{CN}$. [14]

2. MANOVA test using test Pillai's Trace, WilksLamda, Hotelling's Trace and Roy's Largest Root. The goal is to test whether there are differences in the average levels of inorganic compounds in groundwater samples and samples of RO filtration at $\alpha 5 \%$ [14]

The MANOVA assumption were the data is multivariate normal distribution and variance matrix is homogeny. The assumption tests used were Shapiro Wilk Normality test and Box's M [15]. If these assumptions were violated, it uses nonparametric MANOVA.

MANOVA with one factor have the model [14],

$$
x_{i j k}=\mu_{k}+\tau_{i k}+\varepsilon_{i j k}
$$

Where,

$\mathrm{x}=$ the dependent variable

$\mu=$ the mean of $x$

$\tau=$ factor effect/treatment

$\varepsilon=$ error

$\mathrm{i}=$ level of effect, $\mathrm{i}=1,2, \ldots$

$\mathrm{j}=$ the replication, $\mathrm{j}=1,2, \ldots$

$\mathrm{k}=$ number of dependent variable

The significant test uses the $\mathrm{F}$ and $\mathrm{P}$ value from the results of MANOVA table. Reject Ho if $\mathrm{F}>\mathrm{F}_{(\mathrm{df1}, \mathrm{df} 2, \alpha)}$ or $\mathrm{P}$ value $<\alpha$. 
In this research the dependent variable was $\mathrm{Mn}, \mathrm{Cr}, \mathrm{Cd}, \mathrm{Pb}$, and $\mathrm{CN}$. The factor was type of water, consist of 2 levels: ground water and water after RO filtration.

\section{Results And Discussion}

The analysis in this study include descriptive analysis, test for normality, homogeneity testing, and Multivariate Analysis of Variance (MANOVA) for inorganic substances $\mathrm{Mn}, \mathrm{Cr}, \mathrm{Cd}, \mathrm{Pb}$, and $\mathrm{CN}$ in the ground water. Levels of these substances were divided into two groups based on water samples, i.e. the samples of raw water (control) or ground water and the results of filtration water by Reserve Osmosis (RO).

\begin{tabular}{|c|c|c|c|c|}
\hline Samples & Mean & $\begin{array}{l}\text { Standard } \\
\text { Deviation }\end{array}$ & Min & Max \\
\hline $\mathrm{G}$ & 0,0127 & 0,0051 & 0,0030 & 0,0180 \\
\hline round Water & & & & \\
\hline $\begin{array}{ll}- & \mathrm{R} \\
\text { O water } & \\
\text { filtration } & \end{array}$ & 0,0024 & 0,0030 & $-0,0060$ & 0,0090 \\
\hline
\end{tabular}

From the Table 1, it can be seen that the average levels of substance Chromium $(\mathrm{Cr})$ after in RO filtration was lower than in ground water. It was $0.0127 \mathrm{mg} / \mathrm{l}$ in ground water and $0.0024 \mathrm{mg} / \mathrm{l} \mathrm{in} \mathrm{RO}$. Cr levels in the Ground water and RO filtration results still eligible of the values recommended by PAK-EPA and WHO [16] or the standard of Indonesian Ministry of Health $0.05 \mathrm{mg} / 1$.

\begin{tabular}{|c|c|c|c|c|}
\hline Samples & Mean & $\begin{array}{l}\text { Standard } \\
\text { Deviation }\end{array}$ & Min & Max \\
\hline $\begin{array}{l}- \\
\text { round Water }\end{array}$ & 1,5233 & 0,4717 & 1,000 & 3,500 \\
\hline $\begin{array}{l}\text { - } \\
\text { O water } \\
\text { filtration }\end{array}$ & 0,1767 & 0,1194 & 0,000 & 0,300 \\
\hline
\end{tabular}

The average levels of substance Manganese (Mn) RO filtration results lower than in groundwater (see Table 2). Mn levels in the ground water still higher than the values recommended by PAK-EPA and WHO or the standard of Indonesian Ministry of Health $0,5 \mathrm{mg} / \mathrm{l}$. It was perform that quality of $\mathrm{Mn}$ in ground water was poor. Otherwise, RO water filtration results still eligible of the values recommend.

\begin{tabular}{|c|c|c|c|c|}
\hline Samples & Mean & $\begin{array}{l}\text { Standard } \\
\text { Deviation }\end{array}$ & Min & Max \\
\hline $\begin{array}{l}- \\
\text { round Water }\end{array}$ & 0,0058 & 0,0007 & 0,0050 & 0,0070 \\
\hline $\begin{array}{l}\text { - } \mathrm{R} \\
\text { O water } \\
\text { filtration }\end{array}$ & 0,0027 & 0,0012 & 0,0010 & 0,0050 \\
\hline
\end{tabular}

Such as Mn, the average level of Cadmium (Cd) in RO filtration was lower than in groundwater (see Table 3). Cd levels in the ground water still higher than the values recommended by PAK-EPA and WHO or the standard of Indonesian Ministry of Health $0.003 \mathrm{mg} / \mathrm{l}$, but in RO water filtration was still eligible.

\begin{tabular}{|c|c|c|c|c|}
\hline Samples & Mean & $\begin{array}{l}\text { Standard } \\
\text { Deviation }\end{array}$ & Min & Max \\
\hline G & 0,0060 & 0,0030 & 0,0040 & 0,0090 \\
\hline \multicolumn{5}{|l|}{ round Water } \\
\hline $\mathrm{R}$ & 0,0021 & 0,0009 & 0,0010 & 0,0030 \\
\hline $\begin{array}{l}\mathrm{O} \text { water } \\
\text { filtration }\end{array}$ & & & & \\
\hline
\end{tabular}

Lead $(\mathrm{Pb})$ in ground water was $0.0060 \mathrm{mg} / \mathrm{l}$ and in RO filtration was $0.0021 \mathrm{mg} / \mathrm{l}$ (see Table 4). Average of Pb in RO filtration was lower than in groundwater. But all of them still eligible of the values recommended by PAK-EPA and WHO or the standard of Indonesian Ministry of Health $0.01 \mathrm{mg} / \mathrm{l}$. As well as for Cyanide (CN), the average in RO filtration was lower than in groundwater. But all of them still eligible of $0.007 \mathrm{mg} / 1$ (see Table 5). 


\begin{tabular}{|c|c|c|c|c|}
\hline Samples & Mean & $\begin{array}{l}\text { Standard } \\
\text { Deviation }\end{array}$ & Min & Max \\
\hline $\begin{array}{l} \\
\text { round Water }\end{array}$ & 0,0040 & 0,0008 & 0,0030 & 0,0050 \\
\hline $\begin{array}{l}\text { O water } \\
\text { filtration }\end{array}$ & 0,0023 & 0,0008 & 0,0010 & 0,0040 \\
\hline
\end{tabular}

\section{Multivariate Normality Test}

Before conduct the MANOVA analysis, it performed the multivariate normal assumption. The hypothesis used is as follows:

$\mathrm{H}_{0}$ : The data follow a normal distribution multivariate distribution.

$\mathrm{H}_{1}$ : The data do not follow the distribution of a multivariate normal distribution.

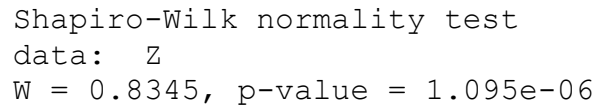

FIGURE 1. Output of Multivariate Normality Test

It was use Shapiro Wilk test in R. From the results, it can be seen that Pvalue is 0.07247 (see Figure 1). It was less than $\alpha=5 \%$, so the data content of $\mathrm{Mn}, \mathrm{Cr}, \mathrm{Cb}, \mathrm{Pb}$, and $\mathrm{CN}$ were not follow a multivariate normal distribution. So the MANOVA assumption was violated.

\section{Multivariate Homogeny Test}

The second assumption of MANOVA analysis is homogeneity of variant of covariance matrix. This study use Box's $M$ to test the homogeneity. Hypotheses used are:

$\mathrm{H}_{0}$ : variance covariance matrix homogeneous

$\mathrm{H}_{1}$ : variance covariance matrix is not homogeneous

\begin{tabular}{cc}
\multicolumn{2}{c}{ TABLE 6. Box's M Test } \\
\hline Box's M & P value \\
\hline 7,344 & 0,000 \\
\hline
\end{tabular}

The test results by SPSS are presented in Table 6 . The conclusion is reject Ho or variance covariance matrix is not homogeneous. So, the MANOVA assumption was violated. This is indicated by the value $\mathrm{P}$ value $=0.000$ which less than $\alpha=5 \%$.

\section{Manova}

MANOVA test was done through test Pillai's Trace, Wilks' Lambda, Hotelling's Trace, and Roy's Largest Root. The hypothesis used is

$\mathrm{H}_{0}$ : There is no difference in the average levels of inorganic substances $\mathrm{Mn}, \mathrm{Cr}, \mathrm{Cd}, \mathrm{Pb}$, and $\mathrm{CN}$

$\mathrm{H}_{1}$ : There are differences in average levels of inorganic substances $\mathrm{Mn}, \mathrm{Cr}, \mathrm{Cd}, \mathrm{Pb}$, and $\mathrm{CN}$

Decision making is the reject Ho if the $\mathrm{P}$ value less than $\alpha$. The test results showed that the value of $\mathrm{P}$ value on all testing is less than $\alpha=5 \%$. So the conclusion is that Ho rejected or there are differences in average levels of inorganic substances $\mathrm{Mn}, \mathrm{Cr}, \mathrm{Cd}, \mathrm{Pb}$, and $\mathrm{CN}$ between before and after $\mathrm{RO}$ filtration.

TABLE 7. MANOVA Test

\begin{tabular}{llccccc}
\hline & Effect & Value & F & df 1 & df 2 & P value \\
\hline Intercept & Pillai's Trace & 0,999 & 8065 & 5,000 & 54,000 & 0,000 \\
& Wilks' Lambda & 0,001 & 8065 & 5,000 & 54,000 & 0,000 \\
& Hotelling's Trace & 746,753 & 8065 & 5,000 & 54,000 & 0,000 \\
& Roy's Largest Root & 746,753 & 8065 & 5,000 & 54,000 & 0,000 \\
\multirow{5}{*}{ Treatment } & Pillai's Trace & 0,938 & 164 & 5,000 & 54,000 & 0,000 \\
& Wilks' Lambda & 0,062 & 164 & 5,000 & 54,000 & 0,000 \\
& Hotelling's Trace & 15,169 & 164 & 5,000 & 54,000 & 0,000 \\
& Roy's Largest Root & 15,169 & 164 & 5,000 & 54,000 & 0,000 \\
\hline
\end{tabular}




\section{Nonparametric MANOVA}

In the MANOVA analysis discussed above, it can be seen that the assumption of normal distribution and homogeneity were not met. Therefore, a comparison analysis was done using a nonparametric MANOVA. Output analysis is presented in Table 8. These results indicate that the value of P value less than $0.001 \alpha=5 \%$. So the conclusion is that Ho rejected or there are differences in average levels of inorganic substances $\mathrm{Mn}, \mathrm{Cr}$, $\mathrm{Cd}, \mathrm{Pb}$, and $\mathrm{CN}$ between before and after RO filtration. It was also performs that RO filtration can be use to get a better water quality in Bekasi, Tangerang, and Jakarta, Indonesia.

TABLE 8. Nonparametric MANOVA Test

\begin{tabular}{lccccc}
\hline \multicolumn{1}{c}{ Source } & df & SS & MS & F & P value \\
\hline Water & 1 & 6,6388 & 6,6388 & 67,512 & 0,001 \\
Residual & 58 & 5,7034 & 0,0983 & & \\
Total & 59 & 12,3422 & & & \\
\hline
\end{tabular}

\section{Conclusion}

From the results of laboratory tests indicate that the groundwater in the area of Bekasi, Tangerang and Jakarta (Indonesia) levels of manganese (Mn) and Cadmium (Cd) above are standardized by the PAK- EPA, WHO or the Indonesian Ministry of Health. But after filtration Reverse Osmosis (RO) Mn and Cd levels decreased to levels below the standardized by PAK- EPA, WHO and Indonesia Ministry of Health. Generally, all the inorganic compounds in ground water and $\mathrm{RO}$ filtration were difference. The average in RO was less than in ground water. It was supported by MANOVA analysis. In $\alpha=5 \%$, it conclude that there are differences in average levels of inorganic substances $\mathrm{Mn}, \mathrm{Cr}, \mathrm{Cd}, \mathrm{Pb}$, and $\mathrm{CN}$ between before (ground water) and after $\mathrm{RO}$ filtration.

\section{Anknowledgment}

Thanks to the Directorate General of Higher Education, Ministry of Education of the Republic of Indonesia and rector of Bina Nusantara University, Jakarta - Indonesia

\section{References}

[1]. Nestle Waters, 5 water functions in human body, http://www.nestle-waters.com/healthy-hydration/water-fonctions-in-humanbody\#cell (Accessed on 10 April, 2013), 2013.

[2]. A. V. Wiesenberger, The Influence of Minerals in Water. Excerpted from "The Taste of Water", 2001.

[3]. Hexavalent Chrome Contamination Treatment for Public Drinking Supply".http://www.water.siemens.com/en/applications/groundwater_remediation/Pages/IPW_ace_services_colby_kansas_ca.aspx

[4]. EPA, Basic Information about Cadmium in Drinking Water. http://water.epa.gov/drink/ contaminants/basicinformation/cadmium.cfm (Acessed on 10 April, 2013), 2013.

[5]. K.E. McCluney and R.C. Date, The effects of hydration on growth of the house cricket, Acheta domesticus, Journal of Insect Science, 2008, 8 (32), available online: insectscience.org/8.32

[6]. A.Z. Garizi, V. Sheikh, and A. Sadoddin, Assessment of seasonal variations of chemical characteristics in surface water using multivariate statistical methods. International Journal of Environmental Science and Technology, 2011, 8(3), pp. 581-592.

[7]. HE, Fanyin. Nonparametric MANOVA Approaches for Non-Normal Multivariate Outcomes. 2013. PhD Thesis. University of Pittsburgh.

[8]. H. Finch, Comparison of the performance of nonparametric and parametric MANOVA test statistics when assumptions are violated. Methodology: European Journal of Research Methods for the Behavioral and Social Sciences, 2005, 1(1), pp. 27-38.

[9]. BSN, Water and waste water - Part 8: Test methods for lead (Pb) in Atomic Absorption Spectrophotometry (AAS)-flame, SNI 6989.8:2009, Jakarta : BSN, 2009.

[10]. BSN, Water and waste water - Part 16: Test method for cadmium (Cd) in Atomic Absorption Spectrophotometry (AAS)-flame, SNI 6989.16:2009, Jakarta: BSN, 2009.

[11]. BPPK, Hexavalent Chromium Test Method 6989.71:2009, http://intranet.bbpk.go.id/pesan/files /35117SNI\%206989_17\%20(krom\%20heksavalen).pdf (Accessed on 20 September, 2013), 2009.

[12]. BSN, SNI-water and waste water-Part 5, SNI 06-6989.5, Jakarta: BSN, 2004.

[13]. BSN, Test Botteld Water, SNI 01-3554-2006, Jakarta : BSN, 2006.

[14]. R. A. Johnson and D. W. Wichern, Applied Multivariate Statistical Analysis, 5th Edition, New Jersey : Prentice Hall, Engelwood Cliffs, 2002.

[15]. D.C. Montgomery, Design and Analysis Of Experiments, 6th Edition, Arizona : John Wiley and Sons, 2005.

[16]. Lenntech, WHO's drinking water standards 1993" .http://www.lenntech.com/applications/drinking/standards/who-s-drinking-waterstandards.htm (Accessed on 20 April, 2013), 2013. 